\title{
A celebration of the life of Marie Öhman (1964-2019)
}

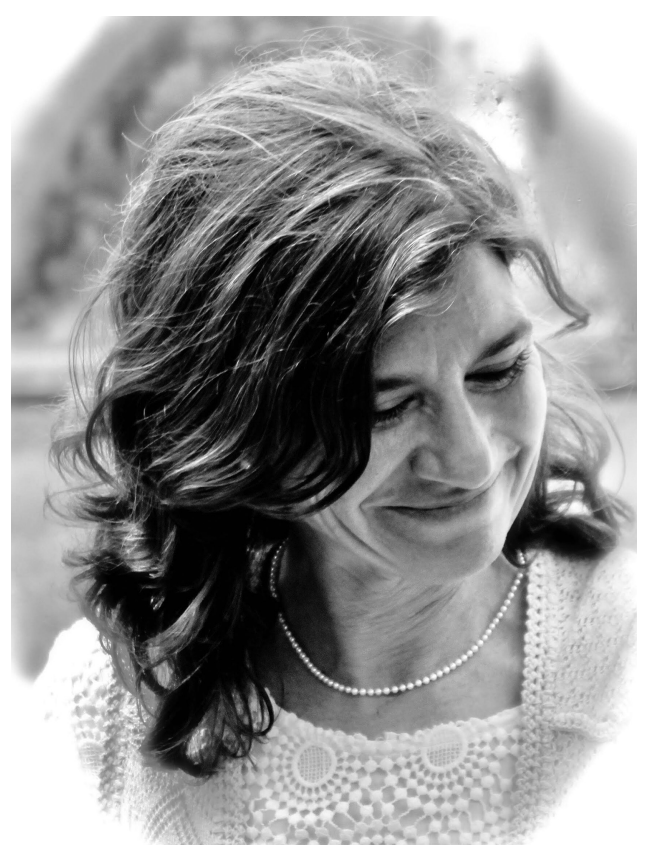

Marie Öhman, Professor of Molecular Biosciences at Stockholm University's Wenner-Gren Institute, died on February 3, 2019. She was a beloved colleague, caring mentor, and a loyal friend, who passionately loved her husband Leif, sons Axel and Isak, and brother Johan.

Marie entered the RNA world during her PhD research with Gerhart Wagner at Uppsala University, where her studies led to important insights into the role of RNA structure in the antisense RNA control of plasmid replication. She also studied bacteriophage introns with Britt-Marie Sjöberg at Stockholm University, before pursuing her postdoctoral work in the laboratory of Brenda Bass at the University of Utah. There she acquired her life-long interest in RNA editing by the adenosine deaminases that act on RNA (ADARs).

Marie was keenly interested in the neuronal functions of ADARs, and her laboratory made diverse scientific contributions in this area, ranging from important mechanistic insight to protocols for the identification of endogenous editing sites. She and her laboratory developed bioinformatics protocols that led to the discovery of a previously unrecognized editing site in the $\mathrm{GABA}_{A}$ receptor, and they were the first to quantify editing from high-throughput RNA sequencing data, allowing them to tackle the challenging task of monitoring editing levels during brain development. Marie was well known for her ability to think about scientific problems in new and creative ways, and this led to unique contributions to the field. She discovered that efficient editing sometimes requires adjacent regions of double-stranded RNA (dsRNA), or "Editing Inducer Elements," thus explaining why certain editing events require long, often bipartite, regions of dsRNA. In collaboration with David Bentley, Marie showed that ADAR editing occurs cotranscriptionally and is coordinated via the carboxy-terminal domain of RNA polymerase II.

Marie's dedication to the support of science was legendary. She cared deeply for the RNA community. In addition to her service on RNA Society committees, she founded the Swedish branch of the RNA Society, organized prominent meetings, and served on the Swedish Research Council. She served on numerous committees toward the evaluation of students and other scientists.

Marie was diagnosed with colon cancer shortly after the 2018 RNA Society meeting in Berkeley. She fought a brave battle, and from the beginning was very open about her condition. Despite her illness, she continued to supervise her students until the end, always putting the needs of others first.

But, as beautifully conveyed by the comments below, there was so much more to Marie. We will hold her close to our hearts forever.

Surrounded by her loved ones, Marie, my dear friend and mentor, passed away at the beginning of February this year. She was a passionate scientist, but she is remembered by many as much more than just a great scientist. She was incredibly supportive, compassionate, and a fun person as well as a great mentor.

—Chammiran Daniel

It was her smile that everyone remembers. It conveyed an openness and generosity of spirit that is usually not associated with scientists. Everyone who knew Marie is likely to remember their first meeting. My first encounter was unforgettable: I met her during a poster presentation at an RNA Society conference in Madison, Wisconsin. She was a postdoctoral fellow in the laboratory of Brenda Bass and was very pregnant at the time with Isak, her second son. I remember this smiling woman who was very round, bouncing along the corridor, full of enthusiasm coming to meet me. Her greeting was something like "So you are the competition," followed by a huge smile. From that moment we were friends; who could resist her?

-Mary O'Connell 


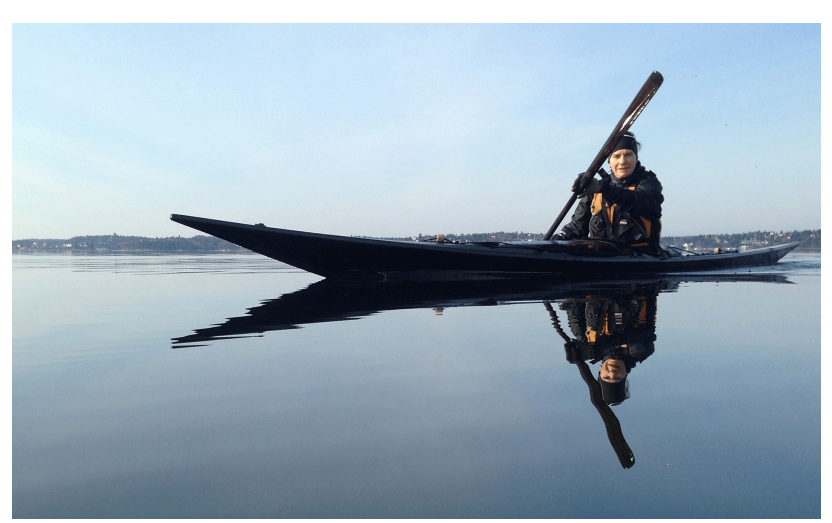

Marie was one of my first PhD students, and she was special. Her family had raised her in the spirit that you can achieve whatever you want. This mindset became one of her most defining characteristics. Marie excelled at sports. She was a world-class skier, a national elite fencer, loved to kayak, and did crazy things like parachuting. Her fearless and, in a friendly way, competitive streak showed in how she conducted science. One of my fondest memories shows, in a nutshell, her characteristic spirit: Marie was pipetting at the bench, apparently in severe pain. She came and told me "Sorry, but I think I need to see a doctor." She had her appendix removed within the hour. To my shock, she was back at the bench, two days later. That was trademark Marie. She has always been such a warm and funny person, and I miss her smile.

-Gerhart Wagner

After finishing her PhD she did her postdoctoral work in my laboratory at the University of Utah from 1998 to 2000, and here she started her lifelong studies of the ADAR family of RNA editing enzymes. I remember Marie as a bold scientist, who was always excited about new ways of thinking about things. She put her heart and soul equally into her lab, family, and fun, and would sometimes show up to lab in her ski clothes. Former lab members remember Marie as an extremely sincere and kind person. Yet, with a twinkle in her beautiful blue eyes, she took great pleasure in gently teasing her friends. Chuckling to herself, she might say, "You know of course that sweetbreads are not actually bread at all-don't you?" Former lab members who interacted with Marie after she left my lab, noted that Marie's students had a deep respect for her and loved her dearly. She fostered the best qualities in her students, such as counseling them to trust other scientists and talk about their unpublished work.
Marie and I started as junior group leaders at approximately the same time in the 90s and realized early on that we needed to support each other. We were a group of young Pls who worked hard to establish ourselves, and Marie, with all her energy, took a leading role gluing us together both scientifically and socially. With Marie's warmth and friendly ways, we immediately became more than colleagues: we became really good friends. She was the one helping me to buy my first car, and when we refurbished our house, we visited numerous building suppliers together. Professionally, Marie also readily shared her science and was always ready to help others. Over the years we had many discussions, and Marie always gave excellent advice on methods and approaches. Marie was an excellent scientist with exceptional dedication to her science and was rewarded by her hard work with a Research Council position and a senior lectureship. In addition, Marie never shunned collegial work, taking on many administrative roles at the University, the department, and in the Research council. Her endless source of ideas, and will to execute those, will be sorely missed, and her passing away is a great loss both for me personally and for the University.

—Anki Östlund-Farrants

I was one of Marie's first PhD students, just after she returned from her postdoctoral work in the USA. Marie was young, strong, brave and courageous, and muscled her way into Stockholm University, starting her own research group. Marie was very good at establishing contacts and collaborations with other scientists. It was super-exciting to have been a PhD student in her group and having Marie as a mentor. She was a role model in how to collaborate, to be inclusive, and to share. We continued to be in contact after I left academia. It was always great fun to meet with her regularly and hear her enthusiastically tell me about her research projects and family. I will miss her so much!

-Johan Ohlson

Marie was my PhD supervisor between 2011 and 2017 and had a great impact on my life and professional development. She allowed me and all of us who walked into her lab to develop as individuals and to own our achievements without feeling threatened. The lab was always filled with music and laughter, and every now and then we exchanged it for a kayak trip or a glass of wine. She was a great woman and will be remembered as such! As a supervisor, Marie was creative, caring, and supportive. She listened to me practice my conference presentations 
over and over and over again... and over again. She was constantly willing to help even though often her deadlines were severely overdue or the hour was very late. She laughed (and liked to participate) when we were doing silly things and performing pranks in her lab. She was always smiling, even when I broke expensive equipment. At times, things weren't easy but later we would laugh together about it. A quality that I believe Marie had that made her a successful and much loved mentor was her ability to motivate us, her students, to take on new challenges, knowing that she had our backs. After being a PhD student in Marie's lab, I feel confident as a scientist and I owe this to her.

-Mikaela Behm

As a supervisor and mentor, Marie had two distinct qualities. One was her overwhelming enthusiasm and the sense of joy for science that she both implicitly and explicitly communicated to all of her students. Another was that she insisted on being a member of her own group, to be treated on the same level as everyone else. Standing beside her students doing bench work was more of a rule than an exception. In addition, Marie had a genuine care for, and personal interest in, her students. By sharing and receiving dayto-day personal trivialities and troubles, she always made her students feel important, and together with her passion for science, she brought out the best in them. Many of her students have declared their postgraduate years "as the best of my life." It is worth saying that Marie's group, despite her demise, is still performing novel and important research. Marie's former students, scattered around the world, are performing groundbreaking research, endeavoring to emulate her. Those who now themselves are shaping the researchers of tomorrow are instilling in them Marie's joyful, intelligent, and enthusiastic way of being a scientist and a fellow (wo)man.

\section{-Mats Ensterö}

Marie had a contagious enthusiasm for research and was a very creative thinker. She could come up with a new idea for a project once a week! She was never the type of supervisor that liked to micromanage. She realized that her students worked best when they were given independence. She was very good at giving opportunities to people to join her group who might not have succeeded well elsewhere and gave them an environment in which they performed well.

-Albin Widmark
Marie was a fantastic supervisor. She made a strong impression on me right from the beginning as being a warmhearted and ambitious person. She was very open in both critique and praise, and her enthusiasm, honesty, and caring personality contributed to an open and motivating atmosphere in the group.

-Victor Karlström

I had just arrived in Sweden to set up my lab. Nobody knew me, and I didn't know anyone. I met a PhD student from Marie's lab at a Gordon Conference. He asked me what my research topic was. "RNA modifications," I said. "Do you work on RNA modifications in Sweden? Does Marie know?" he said. Such an unusual question made a lot of sense afterward when I met Marie. She introduced me to the Swedish RNA Society and gave me the opportunity to organize the next meeting. Later, she introduced me to the COST/European Epitranscriptomic Network. She also helped me to become more visible by inviting me to national meetings. Marie was an extremely generous person. I wish we could all learn from her and welcome foreign young researchers as she did.

-Francesca Aguilo

Marie was a dear friend. I admired her passion for science, her dedication to her department and university, and most of all her commitment to her colleagues. She deeply cared about so many in the RNA community and was always ready to lend a helping hand to those who needed her. She will be sorely missed.

-Mariano Garcia-Blanco

\section{Acknowledgments}

We thank the numerous people who offered suggestions and memories for this article.

Brenda L. Bass

Department of Biochemistry, University of Utah Salt Lake City, Utah 84112, USA

Mary A. O'Connell

CEITEC Masaryk University, Brno 625 00, Czech Republic

E. Gerhart H. Wagner

Department of Cell and Molecular Biology Uppsala University, Uppsala 75124, Sweden 

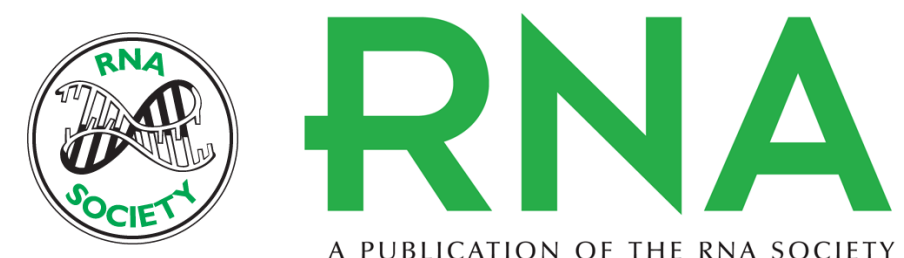

A PUBLICATION OF THE RNA SOCIETY

\title{
A celebration of the life of Marie Öhman (1964-2019)
}

\author{
Brenda L. Bass, Mary A. O'Connell and E. Gerhart H. Wagner
}

RNA 2019 25: ix-xi originally published online July 16, 2019

Access the most recent version at doi:10.1261/rna.072645.119

\section{License}

Email Alerting Receive free email alerts when new articles cite this article - sign up in the box at the Service top right corner of the article or click here.

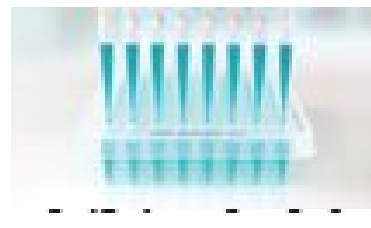

\section{Providing Precise Solutions for} your research.

To subscribe to RNA go to:

http://rnajournal.cshlp.org/subscriptions

Published by Cold Spring Harbor Laboratory Press for the RNA Society 